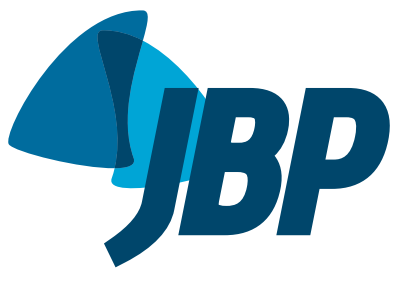

\title{
Reasons for smoking or reasons for quitting, that is the question: can administering the Modified Reasons for Smoking Scale make a difference in clinical practice?
}

\author{
Alberto José de Araújo,a
}

\begin{abstract}
Smoking continues to lead the endless marathon of risk factors that contribute to the occurrence of chronic noncommunicable diseases, being a target for the implementation of the global action plan for the prevention and control of noncommunicable diseases by $2020^{(1)}$ and of the 2030 Agenda for Sustainable Development, (2) both developed by the World Health Organization.
\end{abstract}

As the leading cause of preventable disease worldwide, smoking directly accounts for one sixth of all deaths worldwide and kills eight million people every year, ${ }^{(3)}$ 156,000 being in Brazil. ${ }^{(4)}$

Along with the pressure exerted by the introduction of electronic cigarettes and heated cigarettes, new waves produced by the tobacco industry on the Internet and targeted at adolescents and young adults have led to an unprecedented tobacco epidemic, detected by the Food and Drug Administration in the USA in 2018. ${ }^{(5)}$ This may undermine the efforts of the World Health Organization Framework Convention on Tobacco Control. ${ }^{(6,7)}$

Despite the excellent results of tobacco control policies in Brazil through a set of measures targeted at preventing smoking initiation and reducing tobacco consumption, ${ }^{(8)}$ there are still 18 million smokers requiring a smoking cessation approach. ${ }^{(9)}$ Brazil is one of the countries that have been pioneers in the provision of smoking cessation treatment via the public health care system, as foreseen in Article 14 of the Framework Convention on Tobacco Control. (7) Scientific evidence has demonstrated that the approach to smokers requires, in addition to cost-effective intervention programs based on behavioral counseling associated with pharmacotherapy, ${ }^{(10)}$ the recognition of physical, emotional, and behavioral factors that favor, condition, stimulate, or maintain nicotine dependence. ${ }^{(11)}$ Among these factors, it is important that the physician considers the smoker's perception of health risks associated with tobacco consumption and the extent to which this perception may influence the smoker's motivation to quit smoking.

In addition to the traditional scale introduced by Karl Fagerström for assessing the level of nicotine dependence, other scales have been tested and validated for assessing the context of factors related to motivation, self-efficacy, levels of anxiety and depression, reasons for smoking, and motivational stages of change. ${ }^{(12)}$

Training for administering most of these scales is simple, and their administration takes little time during the initial clinical evaluation of smokers and makes it possible to know predictors of and obstacles to smoking prevention, smoking cessation, and maintenance of abstinence, as well as factors that maintain individuals oscillating as to behavioral changes, that is, in a state of ambivalence. ${ }^{13,14)}$

In general, smoking is described by many individuals as a means to control their feelings. Tomkins ${ }^{(15)}$ described four basic motivational characteristics of the behavior of smokers: smoking to increase a pleasant/positive affect; smoking to reduce a negative affect; smoking as a habit or without seeking to mitigate/increase any affect; or smoking because of addiction. These characteristics require working with positive and negative affects. On the basis of this model, the Reasons for Smoking Scale (RSS) was created, being originally composed of 23 items and six subscales: manipulation; pleasure; habit/ automatism; stimulation; tension reduction/relaxation; and addiction. ${ }^{(16,17)}$

The Modified Reasons for Smoking Scale (MRSS) ${ }^{(18)}$ consists of 21 questions and seven subscales. The MRSS is a widely accepted scale that provides the opportunity of a more thorough assessment of the smoker and a more detailed psychological profile. In addition, the MRSS is practical to use because it is short, taking only a few minutes to complete.

Different language versions of the MRSS have confirmed its validity and reliability. Berlin et al. ${ }^{(18)}$ tested the French-language version of the MRSS in male and female smokers who participated in a smoking cessation program and had a strong intention to quit. The Dutch-language version of the MRSS was tested in male and female smokers who also had a strong intention to quit. ${ }^{(19)}$ The Brazilian Portuguese-language version of the MRSS was tested by de Souza et al.(20) in male and female blood donors who had no intention to quit smoking.

The MRSS has been used in studies of subgroups of smokers. A longitudinal study of 97 pregnant smokers evaluated the psychological and social factors possibly related to smoking cessation during pregnancy. The most important reason for continuing to smoke was found to be emotional tension reduction, followed by pleasure and addiction. ${ }^{(21)}$ Other studies reported that, although pregnant women were aware of the smoking-related risks to the fetus's health, that awareness was insufficient to motivate them to quit smoking. ${ }^{(22,23)}$ One study suggested that nicotine dependence is the most important health barrier to smoking cessation during pregnancy. ${ }^{(24)}$ 
In this issue of the JBP, Rocha et al. ${ }^{(25)}$ published a cross-sectional, population-based study in which they used the University of São Paulo MRSS, validated for use in Brazil, ${ }^{(26)}$ and evaluated the scale domain scores by demographic variable (gender, socioeconomic class, and level of education), smoking history (pack-years), mood disorder (anxiety and depression), and spirometric diagnosis of COPD.

The study mainly focused on identifying factors involved in tobacco consumption in order to address nicotine dependence prevention and smoking cessation counseling. The authors highlighted the importance of information about the reasons that maintain individuals smoking, which is a relevant distinguishing feature compared with other studies because it helps to develop smoking cessation strategies.

Therefore, knowing and administering the MRSS enables the physician to have a better approach to smoking cessation. This is an extraordinary tool that allows assessment of motives for smoking.

\section{REFERENCES}

1. World Health Organization [homepage on the Internet]. Geneve: World Health Organization; [cited 2019 Jul 1]. Global action plan for the prevention and control of noncommunicable diseases 2013-2020. 2013 [Adobe Acrobat document, 55p.]. Available from: https://apps. who.int/iris/bitstream/handle/10665/94384/9789241506236_eng.pdf jsessionid $=2235 D 53 F B 5 A E 4 D 97 B 5 E F A 7 D 00118 E F 90$ ? sequence $=1$

2. World Health Organization [homepage on the Internet]. Geneve: World Health Organization; [updated 2018 Dec 24; cited 2019 Jul 1]. Implementation of the 2030 Agenda for Sustainable Development: Report by the Director-General. 2018 [Adobe Acrobat document, 16p.]. Available from: https://apps.who.int/gb/ebwha/pdf_files/EB144/ B144_11Rev1-en.pdf

3. World Health Organization [homepage on the Internet]. Geneve: World Health Organization; [updated 2019 Jul 29; cited 2019 Aug 4] Tobacco. [about 9 screens]. Available from: http://www.who.int/en/ news-room/fact-sheets/detail/tobacco

4. Pinto M, Bardach A, Palacios A, Biz A, Alcaraz A, Rodríguez B, et al Carga de doença atribuível ao uso do tabaco no Brasil e potencia impacto do aumento de preços por meio de impostos [monograph on the Internet]. Buenos Aires: Instituto de Efectividad Clínica y Sanitária; 2017. http://actbr.org.br/post/carga-de-doenca-atribuivel-aouso-do-tabaco-no-brasil-e-potencial-impacto-do-aumento-de-precospor-meio-de-impostos/17570/

5. McCausland K, Maycock B, Leaver T, Jancey J. The Messages Presented in Electronic Cigarette-Related Social Media Promotions and Discussion: Scoping Review. J Med Internet Res. 2019;21(2):e11953. https://www.jmir.org/2019/2/e11953/pdf

6. Glantz SA, Bareham DW. E-Cigarettes: Use, Effects on Smoking Risks, and Policy Implications. Annu Rev Public Health. 2018:39:215 235. https://www.annualreviews.org/doi/10.1146/annurevpublhealth-040617-013757

7. Brasil. Ministério da Saúde. Instituto Nacional de Câncer José Alencar Gomes da Silva (INCA) [homepage on the Internet]. Rio de Janeiro: INCA [cited $2019 \mathrm{Jul} 1$ 1]. Convencão-Quadro para Controle do Tabaco: Texto Oficial. 2015. [Adobe Acrobat document, 62p.]. Available from: https://www.inca.gov.br/sites/ufu.sti.inca.local/files//media/ document//convencao-quadro-para-controle-do-tabaco-texto-oficial. pdf

8. Levy D, de Almeida LM, Szklo A. The Brazil SimSmoke policy simulation model: the effect of strong tobacco control policies on smoking prevalence and smoking-attributable deaths in a middleincome nation. PLoS Med. 2012:9(11):e1001336. https://doi. org/10.1371/journal.pmed.1001336

9. Brasil. Ministério da Saúde [homepage on the Internet]. Brasilia: Ministério da Saúde [cited 2019 Jul 1]. VIGITEL Brasil 2017-Vigilância de Fatores de Risco e Proteção para Doenças Crônicas por Inquérito Telefônico. 2018 [Adobe Acrobat document, 132p.]. Available from: http://bvsms.saude.gov.br/bvs/publicacoes/vigitel_brasil_2017_ vigilancia fatores riscos.pdf

10. Reichert J, Araújo AJ, Gonçalves CM, Godoy I, Chatkin JM, Sales MP, et al. Smoking cessation guidelines-2008. J Bras Pneumo 2008;34(10):845-80. http://jornaldepneumologia.com.br/detalhe_ artigo.asp?id=817

11. Coelho R. Quais são os principais comportamentos relacionados com 0 ato de fumar? In: Sociedade Brasileira de Pneumologia e Tisiologia Manual de Condutas e Práticas em Tabagismo. Rio de Janeiro: AC

Farmacêutica: 2012

12. Halty L. Quais são os testes para aferir a dependência a nicotina? In: Sociedade Brasileira de Pneumologia e Tisiologia. Manual de Condutas e Práticas em Tabagismo. Rio de Janeiro: AC Farmacêutica; 2012

13. Miller WR, Rollnick S. Motivational Interviewing: Helping People Change. 3rd ed. New York, NY: The Guilford Press; 2012

14. Marlatt GA, Donovan DM, editors. Relapse prevention: maintenance strategies in the treatment of addictive. 2nd ed. New York, NY: The Guilford Press; 2007

15. Tomkins SS. A psychological model for smoking behavior. Am J Public Health Nations Health. 1966;56(12):Suppl 56:17-20.

16. Horn D, Waingrow S. Behavior and Attitudes Questionnaire. Bethesda: National Clearinghouse for Smoking and Health; 1966.

17. Ikard F, Green DE, Horn D. A scale to differentiate between types of smoking as related to the management of affect. Int $\mathrm{J}$ Addict. 1969;4(4):649-659

18. Berlin I, Singleton EG, Pedarriosse AM, Lancrenon S, Rames A, Aubin HJ, Niaura R. The Modified Reasons for Smoking Scale: factorial structure, gender effects and relationship with nicotine dependence and smoking cessation in French smokers. Addiction. 2003;98(11):1575-83. https://doi.org/10.1046/j.1360 0443.2003.00523.x

19. Boudrez H, De Bacquer D. A Dutch version of the Modified Reasons for smoking Scale: factorial structure, reliability and validity. J Eva Clin Pract. 2012;18(4):799-806. https://doi.org/10.1111/].1365 2753.2011.01676.x

20. de Souza ES, Crippa JA, Pasian SR, Martinez JA. Factorial structure of the Brazilian version of the Modified Reasons for Smoking Scale [Article in Portuguese]. Rev Assoc Med Bras (1992). 2009;55(5):55762.

21. De Wilde KS, Tency I, Boudrez H, Temmerman M, Maes L, Clays E. The Modified Reasons for Smoking Scale: factorial structure, validity and reliability in pregnant smokers. J Eval Clin Pract. 2016;22(3):40310. https://doi.org/10.1111/jep.12500

22. Gilman S, Breslau J, Subramanian S, Hitsman B, Koenen K. Socia factors, psychopathology, and maternal smoking during pregnancy. Am J Public Health. 2008;98(3):448-53. https://doi.org/10.2105/ AJPH.2006.102772

23. da Motta Gde E, Echer IC, Lucena Ade F. Factors associated with smoking in pregnancy. Rev Lat Am Enfermagem. 2010;18(4):809-15. https://doi.org/10.1590/S0104-11692010000400021

24. De Wilde K, Trommelmans L, Laevens H, Maes L, Temmerman M Boudrez H. Smoking patterns, depression, and sociodemographic variables among Flemish women during pregnancy and the postpartum period. Nurs Res. 2013;62(6):394-404. https://doi. org/10.1097/NNR.0b013e3182a59d96

25. Rocha SAV, Hoepers ATC, Fröde TS, Steidle LJM, Pizzichini E, Pizzichin MMM. Prevalence of smoking and reasons for continuing to smoke: a population-based study. J Bras Pneumol. 2019:45(4):e20170080. https://doi.org/10.1590/1806-3713/e20170080

26. Souza ES, Crippa JA, Pasian SR, Martinez JA. University of São Paulo Reasons for Smoking Scale: a new tool for the evaluation of smoking motivation. J Bras Pneumol. 2010;36(6):768-78. http://dx.doi. org/10.1590/S1806-37132010000600015. 